\title{
Effects of Fruit Thinning and Percentage of Retained- Fruitlets on Fruit Quantity and Quality of Siam Mandarin Cultivar at Kintamani, Bali, Indonesia
}

\author{
Santirupini I.A. ${ }^{1}$, Agung IG.A.M.S. ${ }^{2}$, Nurjaya IG.M.O. ${ }^{3}$ \\ ${ }^{1,2}$ Master Study Program for Dryland Agriculture , Udayana University, Bali, Indonesia \\ ${ }^{3}$ Study Program for Biology, Udayana University, Bali, Indonesia
}

\begin{abstract}
Fruit thinning in Siam mandarin (Citrus nobilis var microcarpa L.) has been applied in order to improve quality of the fruit involving bigger or higher fruit weght, the sweet of the fruit hence higher market price. The experiment of hand thinning was conducted in farmer's orchard in Bayung Gede village, district of Kintamani, Bangli regency, Indonesia province from 18 June until September 2015. The objective of the experiment was to investigate the effects of stage of fruit thinning and percentage of retained fruitlets on quantity and quality of fruits of siam mandarin cultivar. A randomized complete block design with three replicates was used in the experiment. Two treatment factors were the stage of fruit thinning (stage of fruitlet size of $10 \mathrm{~mm}$, $30 \mathrm{~mm}$ and $50 \mathrm{~mm}$ ) and percentage of retained fruitlet on a branch (100\%, 75\%, 50\% and 25\%). Results of experiment showed that thinning at the stage of $30 \mathrm{~mm}$ fruitlet size significantly increased fruit diameter fruit diameter, weight fruit ${ }^{-1}$, and fruit weight bunch $^{-1}$. Thinning at the stage of $50 \mathrm{~mm}$ fruitlet size could only increase sugar content in the fruit of siam mandarin when retained fruitlets on the branch were 25\%. Thinning at the stage of $10 \mathrm{~mm}$ and $30 \mathrm{~mm}$ fruitlet sizes resulted in higher ratio of sugar:acid content (7.34 and 7.39 respectively) than thinning at that of $50 \mathrm{~mm}$. The size of fruit (diameter and fruit weight) and ratio of sugar:acid content were not significantly affected by percentage of retained fruitlets on a branch.
\end{abstract}

Keywords- Fruit thinning, fruit size, ratio of sugar:acid content, Siam mandarin (Citrus nobilis var microcarpa $L$.).

\section{INTRODUCTION}

Siam mandarin cultivar (Citrus nobilis var microcarpa L.) is one of citrus species grown in district of Kintamani, Bangli regency, Bali province of Indonesia. As a species with many small fruits (1000-2000 fruits year $\left.{ }^{-1}\right)$ give this species fruit quantity and quality problem. Quantity problems involve too many small fruits bunch ${ }^{-1}$. Due to high competition for assimilates among fruits particularly on a branch, the size of fruits are mostly small, fruit taste more sour than sweet and sometimes suffered from pathogen which become quality problems. Those problems consequently result in lower price of this commodity. Too many fruits on a tree can cause over weight to the tree and less and uneven of sunlight penetration and oxygen circulation to the fruits.This condition could result in increasing number of fruit lost. Bigger fruits have more cells compared to smaller fruits. Fruits produced by unheavy trees will have bigger cells than those heavy ones (Ouma, 2012). One way to increase the quality of citrus fruits is by thinning. Fruit thinning is defined as reducing flowers or flower cluster or fruitlets after fruit set (Ouma, 2012). Fruit thinning is conducted to reduce number of fruits on a bunch or branch (Hardy, 2008). The ideal fruit number of siam mandarin is 6-8 fruits bunch ${ }^{-1}$. Fruit thinning has been done citrus farmers (mandarin and navel orange) in Washington (Hardy, 2008) or in other citrus production center for export. Fruit thinning is usually imposed at the beginning of II stage of fruit growth (stage of cell expansion) at stage of $30-40 \mathrm{~mm}$ fruitlet size. Fruitlets size of $<30 \mathrm{~mm}$ more difficult to find in the canopy (Hardy, 2008), while those of $>40 \mathrm{~mm}$ will be too big to discard.

In Indonesia, fruits of siam mandarin cultivar has been classified based on weight fruit ${ }^{-1}$ into four class those are A, B, C and D. Class A has fruit diameter of $7,1 \mathrm{~cm}$ or $151 \mathrm{~g}$ fruit $^{-1}$, class $\mathrm{B}$ has fruit diameter of $6,1-7 \mathrm{~cm}$ or 101-150 $\mathrm{g}_{\text {fruit }}{ }^{-1}$, class $\mathrm{C}$ has fruit diameter of $5.1-6.0 \mathrm{~cm}$ or 51-100 $\mathrm{g}$ fruit ${ }^{-1}$, class $\mathrm{D}$ has fruit diameter of 4.0-5.0 $\mathrm{cm}$ or $50 \mathrm{~g}_{\text {fruit }}{ }^{-1}$ (Khairani and Dalapati, 2006).

Siam mandarin cultivar at Kintamani, Bali, Indonesia has fruit characteristic of fresh, relatively sour small fruis, yellowish skin colour and productivity of 40-60 kg tree ${ }^{1}$ year $^{-1}$ (Anonymous, 2015b). Siam mandarin farmers in 
Bali have been reluctant to thin their fruits, therefore most fruits produced in the area are relatively small compared to orange species of keprok, hence they could not compete with the price of other imported mandarins or oranges. Besides, there is limited information available on stage of fruit thinning and percentage of retained fruitlets on siam mandarin cultivars. The objective of the present experiment was to investigate the effects of stage of fruit thinning and percentage of retained fruitlets on quantity and quality of fruits of siam mandarin cultivar in Kintamani area.

\section{MATERIALS AND METHODS}

The experiment was conducted at farmer's orchad in Bayung Gede village, district of Kintamani, Bangli regency, province of Bali, Indonesia. The location was at 800-900 m asl with annual amount and day of rainfall arround $142 \mathrm{~mm}$ and 9 days year ${ }^{-1}$. Average temperature was $20-24^{\circ} \mathrm{C}$ (Anonymous, 2015b).

Results of soil analysis of experimental land showed a neutral soil $\mathrm{pH}$ of 6.7 , organic $\mathrm{C}$ of $2.66 \%$ (moderate), total $\mathrm{N}$ of $0.12 \%$ (low), available $\mathrm{P}$ of $576,05 \mathrm{ppm}$ (very high), exchangeable $\mathrm{K}$ of $105,74 \mathrm{ppm}$ (low), and soil texture of loamy sand (Anonymous, 2015c). The experiment was commenced at 18 June until September 2015. The experiment was arranged in a randomized completely block design with three replicates and two treatment factors were imposed. The first factor was stadia of fruit thinning (at fruitlet size of $10 \mathrm{~mm}, 30 \mathrm{~mm}$ and $50 \mathrm{~mm}$ ), while the second factor was percentage of fruitlet retained on a branch $(100 \%, 75 \%, 50 \%$ and $25 \%$ of fruitlet on a branch prior to thinning). Fruitlets at $100 \%$ did not receive any thinning treatment (control).

Thirty six healthy and almost uniform trees having flowers and young fruits on each branch were randomly selected (tagged) for the experiment samples. Hand thinning was imposed using a sterillized scissor on one selected branch at four directions (north, east, west and south). Variable measured involving fruit quantity (fruit number branch ${ }^{-1}$, weight fruit ${ }^{-1}$, fruit weight branch ${ }^{-1}$, leaf number branch ${ }^{-1}$ and ratio of weight fruit ${ }^{-1}:$ leaf number branch $^{-1}$ ) and quality (fruit diameter, sugar content ( ${ }^{\circ}$ brix), citric acid content, ratio of sugar:acids and moisture content). During the experiment there was no fertilizer applied, however cow manure and biofertilizer (finno stimulant) at $25 \mathrm{~kg}$ tree $^{-1}$ and NPK fertilizer at 20 $\mathrm{kg}$ tree $^{-1}$ were applied after harvest. Fungicide (scor) at $0.5 \mathrm{ml} \mathrm{l}^{-1}$ tree $^{-1}$ and insecticide (alika) at $0.5 \mathrm{ml} \mathrm{l}^{-1}$ tree $^{-1}$ were applied as well. Fruits were harvested when they were matured enough indicated by yellowish $(25 \%$ yellow) skin colour and the fruit were not too hard when was pressed. Data were statistically analysis using ANOVA program of Costat and MstatC. Duncan's MRT and Least Significant Different at 5\% level were applied to calculate mean comparisons (Gomez and Gomez, 2007).

\section{RESULTS AND DISCUSION}

Results of statistical analysis showed that fruit thinning had highly $(\mathrm{P}<0,01)$ significant effects on fruit diameter, sugar and citric acid contents, and significantly $(\mathrm{P}>0,05)$ affected ratio sugar:acid content, however it did not affect leaf number branch ${ }^{-1}$ and fruit moisture content. Percentage of retained fruitlets on a branch significantly $(\mathrm{P}<0,01)$ affected only number of fruits bunch $^{-1}$ after thinning, weight of fruits harvested bunch ${ }^{-1}$, leaf number branch $^{-1}$ and ratio of weight fruit ${ }^{-1}$ : leaf number branch ${ }^{-1}$. Interaction between stage of fruit and percentage if retained fruits on a branch only significantly $(\mathrm{P}<0,05)$ affected fruit sugar content ( ${ }^{\circ}$ brix).

\subsection{Interaction Effects Between Stage of Thinning and Percentage of Retained Fruitlets on a Branch}

\subsubsection{Fruit sugar content}

Thinning at stage of $10 \mathrm{~mm}$ and $30 \mathrm{~mm}$ fruit size did not significantly affect fruit sugar content either at $100 \%$ or $75 \%, 50 \%$ and $25 \%$ (Table 1). However when thinning was imposed at stage of $50 \mathrm{~mm}$ fruitlet size with retained fruitlets of $25 \%$, sugar content was increased by $23.35 \%$ (Table 1).

The sweetness of a fruit, which is indicated by sugar content in the fruit is affected by thinning. In the present experiment, high fruit sugar content of $10.67 \%$ resulted from thinning imposed at stage of $50 \mathrm{~mm}$ fruitlet size. That content was $23.60 \%$ higher than that at control (100\% retained fruitlets). The other thinning treatments did not increase fruit sugar content (Table 1), which might be due to fruitlets had been large enough with high fruit sugar content, and competition for assimilates was relatively low among less number of fruitlets (25\%). In the present experiment, sugar content of siam mandarin was higher than standard sugar content $(8 \%)$ for industry in Australia (Anonymous 2009).

\subsection{Individual Effect of Stage of Thinning and Percentage of Fruitlets on a Branch}

\subsubsection{Number of fruits harvested bunch ${ }^{-1}$}

Thinning at stage of $10 \mathrm{~mm}$ fruitlet size resulted in the highest (3.79 fruits) number of fruits bunch ${ }^{-1}$ which was $19.56 \%$ and $51.56 \%$ respectively higher than those thinned at stage of $30 \mathrm{~mm}$ dan $50 \mathrm{~mm}$ fruilett size (Tabel 2 ). Without thinning (retained fruitlets of $100 \%$ ) resulted in the highest number of fruits bunch ${ }^{-1}$ (7.48 fruits). Thinning with retained fruitlets of $75 \%, 50 \%$ and $25 \%$ significantly decreased number of fruits harvested bunch ${ }^{-1}$ respectively $34,27 \%, 65,40 \%$ and $243,89 \%$ compared to those in control treatment. Decreases in number of fruits 
due to thinning is one of the reason for increasing the quality of fruits and finally its marketable price (Falivene and Hardy, 2008). In addition, thinning will reduce the competition for assimilates produced in leaves (sources) then translocated to fruits (sinks) (Goldschmidts and Monselise, 1977; Guardiola 1988).

\subsubsection{Weight fruit $^{-1}$}

Thinning at stage of $30 \mathrm{~mm}$ significantly increased weight fruit $^{-1}$ which made the highest value of $123.95 \mathrm{~g}$, were respectively $29.76 \%$ and $8.80 \%$ compared to those done at the stage of $10 \mathrm{~mm}$ and $50 \mathrm{~mm}$ fruitlet size (Tabel 2). Percentage of retained fruitlets on a branch did not significantly affect weight fruit ${ }^{-1}$. Manual (hand) thinning is an alternative way to increase citrus fruit size (Falivene and Hardy, 2008).

According to Falivene and Hardy (2008) size of fruitlet of $30 \mathrm{~mm}$ is the beginning stage of fruit growth, at which the assimilates produced in photosynthesis process is started to use for cell expansion. That may be due to stronger and more determinate effects of the stage thinning. Falivene and Hardy (2008) also stated that stage of fruitlet size of $30 \mathrm{~mm}-40 \mathrm{~mm}$ is the ideal time to thin citrus. Fruitlets smaller than $30 \mathrm{~mm}$ perhaps still small and have not received adequate assimilates, that is way has not been significantly affected by thinning. In addition the smaller fruits are not easy to see and to find.

Hardy et al. (2003) suggested that in order to obtain bigger fruits and better quality, first fruit thinning is better to impose at the stage of $25-35 \mathrm{~mm}$ through reducing fruit number up to $50 \%$. Thinning at the stage of $>40 \mathrm{~mm}$ fruitlet size may have been entering the stage of cell expansion, that is why its too big to thin.

Thinning results in carbohydrates more available for remaining fruits to grow and develop, reduce the number of fruit loss and increases leaf carbohydrate concentrations in comparison to control. Similar argumentation was also presented by Guardiola and Garcia-Luis (2000) that thinning is expected to increase citrus fruit size.

\subsubsection{Fruit weight bunch $^{-1}$}

Thinning at stage of $30 \mathrm{~mm}$ fruitlet size resulted in high fruit weight bunch ${ }^{-1}(395.64 \mathrm{~g})$, particularly at $75 \%$ retained fruitlets (Table 2). Although that weight was not significantly different from that at stage of $10 \mathrm{~mm}$, it was significantly $30.17 \%$ higher than that at stage of $50 \mathrm{~mm}$ fruitlet size. The lowest fruit weight bunch ${ }^{-1}$ when thinned at stage of $50 \mathrm{~mm}$ fruitlet size was associated with the lowest number of harvested fruits bunch ${ }^{-1}$ (2.50 fruits) (Table 2).

\subsubsection{Fruit diameter}

Thinning at stage of $30 \mathrm{~mm}$ fruitlet size resulted in the biggest fruit diameter $(6.66 \mathrm{~cm})$, which was $10.08 \%$ and $5.55 \%$ bigger respectively than those thinned at stage of
$10 \mathrm{~mm}$ and $50 \mathrm{~mm}$ fruitlet size (Table 3). Percentage of retained fruitlets did not affect fruit diameter. Thinning imposed at stage of $10 \mathrm{~mm}$ resulted in small fruits (fruit diameter of $6.05 \mathrm{~cm}$ ) which was $9.16 \%$ smaller than that thinned at stage of $30 \mathrm{~mm}$ (Table 3)..

\subsubsection{Fruit acid content}

Thinning at stage of $50 \mathrm{~mm}$ fruitlet size gave the highest (1.74 ppm) fruit acid content, which was respectively $41.46 \%$ and $18.37 \%$ higher than those thinned at stage of $10 \mathrm{~mm}$ and $30 \mathrm{~mm}$ (Table 3). Percentage of retained fruitlets did not affect fruit diameter.

\subsubsection{Ratio fruit sugar:acid content}

There was no significantly different ratio of fruit sugar:acid content resulted from thinning at stage of 30 $\mathrm{mm}$ and of $10 \mathrm{~mm}$ fruitlets size, however it was $33,88 \%$ higher than the ratio when thinning was imposed at stage of $50 \mathrm{~mm}$ fruitlet size (Table 3). The highest fruit acid content given by thinning at stage of $50 \mathrm{~mm}$ fruitlet size resulted in lowest ratio of sugar: acid content (5.52:1) (Table 3).Therefore, lower acid content (1.23 ppm) at thinning of stage of $30 \mathrm{~mm}$ fruitlet size gave higher ratio sugar;acid content (7.39:1) compared to that of stage of $50 \mathrm{~mm}$ fruitlet size (Table 3). Although that ratio was considered was still lower than standard for navel orange (10:1), however close enough to that for siam mandarin cultivar (8:1) (Anonymous, 2009).

\subsubsection{Fruit moisture content}

There was no significant effect neither of stage of thinning or percentage of retained fruitlets on a branch (Table 3). Harvested fruits contained on average of $89.03 \%$ moisture. The mandarin trees used in the present experiment were healthy (they were not suffered from serious water deficit and pest and disease), this consequently resulted in no significant difference in fruit moisture as thiining imposed.

\section{CONCLUSSIONS}

Thinning at stage of $30 \mathrm{~mm}$ fruitlet size significantly increased the fruit quantity (weight fruit $^{-1}$, and fruit weight bunch $^{-1}$ ). Meanwhile thinning at stage of $10 \mathrm{~mm}$ and $50 \mathrm{~mm}$ fruitlet size did not significantly increase those variables. The quality of fruit (fruit diameter, sugar and acid content and ratio of fruit sugar: acid content) also increased when thinning was imposed at stage of 30 $\mathrm{mm}$ fruitlet size. .Fruit sugar content only increased when thinning was imposed at stadia of $50 \mathrm{~mm}$ fruitlet size with $25 \%$ retained fruitlets. Thinning at stage of $10 \mathrm{~mm}$ and 30 mm fruitlet size increased ratio of fruit sugar: acid content as much as 7.34 and 7.39 respectively compared to those when thinned at stadia of $50 \mathrm{~mm}$ fruitlet size. Fruit size (diameter and weight fruit $^{-1}$ ) and sweetness (ratio of sugar: acid content) were not significantly affected by percentage of retained fruitlets on a branch. 


\section{ACKNOWLEDGEMENTS}

The authors wish to gratefuly thank the government and the department of agriculture of Bali province Indonesia in providing the research funds. Great appreciation also goes to Mr. Nyoman Sandra for permission to use his citrus orchad.

\section{REFERENCES}

[1] Anonymous. 2015a. Jeruk Dataran Tinggi. http://balijestro.litbang.pertanian. go.id/id/jerukdataran-tinggi.html. In Bahasa Indonesia .Viewed: 6-04-2015.

[2] Anonymous. 2015b. Topografi dan iklim kabupaten Bangli. Dinas Pertanian, Perkebunan dan Kehutanan Kabupaten Bangli. In Bahasa Indonesia.

[3] Anonymous. 2015c. Results of soil analysis. Laboratory of Soil Science, Faculty of Agriculture, Udayana University. In Bahasa Indonesia.

[4] Anonymus. 2009. Government of Western Australia, Department of Agriculture and Food (2009) http://www.agric.wa.gov.au/PC_93298.html Viewed on the 22 July 2009.

[5] Falivene, S. and S. Hardy. 2008. Hand thinning citrus. Primefact 789:1-3a.
[6] Goldschmidt, E.E. and s. P. Monselise, S.P. 1977. Physiological assumptions toward the development of a citrus fruiting model. Proc. Int. Soc. Citriculture. 2:668-672.

[7] Gomez, K.A dan Gomez, A.A. 2007. Statistical Procedures for Agricultural Research (University of Indonesia Press, Jakarta, 2007).

[8] Guardiola J., García-Luis A., 2000. Increasing fruit size in Citrus. Thinning and $s$ timulation of fruit growth. Plant Growth Regul. 31(1-2), 121-132.

[9] Guardiola JL. 1988. Factors limiting productivity in Citrus. A physiological approach. Proceedings of

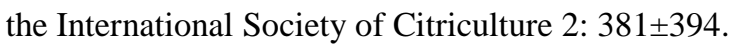

[10] Hardy, S. 2008. Hand Thinning Citrus. NWS of Primary Industries. http://www.dpi.nws.go.au/agricultural/citrus/manage ment/other-informa-tion/hand-thinning Viewed: 24-09-2014

[11] Khairani, C and Dalapati, A. 2006. Penanganan Jeruk Segar. http://repository. unand.ac.id/.../1/06jeruk.pdf. In Bahasa Indonesia.Viewed: 6-04-2015.

[12] Ouma, G. 2012. Fruit thinning with specific reference to Citrus species: a review. ABJNA. 3 , 85-100.

Table.1: Interaction effect between stage of fruit thinning at different fruitlet size and percentage of retained fruitlets on a branch on fruit sugar content

\begin{tabular}{|l|c|c|c|c|}
\hline & \multicolumn{4}{|c|}{ Percentage of retained fruitlets on a branch (\%) } \\
\hline $\begin{array}{l}\text { Stage of thinning } \\
\text { at fruitlet size }\end{array}$ & 100 & 75 & 50 & 25 \\
\hline $10 \mathrm{~mm}$ & $9.88 \mathrm{ab}$ & $10.8 \mathrm{ab}$ & $9.67 \mathrm{ab}$ & $9.83 \mathrm{ab}$ \\
\hline $30 \mathrm{~mm}$ & $9.00 \mathrm{ab}$ & $8.83 \mathrm{ab}$ & $9.25 \mathrm{ab}$ & $8.63 \mathrm{~b}$ \\
\hline $50 \mathrm{~mm}$ & $8.65 \mathrm{~b}$ & $8.95 \mathrm{ab}$ & $9.93 \mathrm{ab}$ & $10.67 \mathrm{a}$ \\
\hline
\end{tabular}

Notes: Means followed by the same letters in the same treatments are not significantly different at 5\% DMRT.

Table.2: Individual effect of fruit thinning stage at different fruitlet size and percentage of retained fruitlets on a branch on number of harvested fruit, weight fruit ${ }^{-1}$, and fruit weight bunch $^{-1}$

\begin{tabular}{|c|c|c|c|}
\hline Treatments & $\begin{array}{c}\text { Number of } \\
\text { harvested fruits }\end{array}$ & $\begin{array}{c}\text { Weight fruit } \\
(\mathrm{g})\end{array}$ & $\begin{array}{c}\text { Fruit weight } \text { bunch }^{-1} \\
(\mathrm{~g})\end{array}$ \\
\hline Stage of thinning at fruitlet size \\
\hline $10 \mathrm{~mm}$ & $3.79 \mathrm{a}$ & $95.52 \mathrm{c}$ & $350.87 \mathrm{a}$ \\
\hline $30 \mathrm{~mm}$ & $3.17 \mathrm{~b}$ & $123.95 \mathrm{a}$ & $395.64 \mathrm{a}$ \\
\hline $50 \mathrm{~mm}$ & $2.50 \mathrm{c}$ & $113.04 \mathrm{~b}$ & $276.26 \mathrm{~b}$ \\
\hline $5 \%$ LSD & 0.592 & 10.855 & 69.56 \\
\hline \multicolumn{5}{|l}{} \\
\hline \multicolumn{1}{|c|}{ Percentage of retained fruitlets on a branch (\%) } \\
\hline 100 & $4.78 \mathrm{a}$ & $111.57 \mathrm{a}$ & $521.37 \mathrm{a}$ \\
\hline 75 & $3.56 \mathrm{~b}$ & $118.25 \mathrm{a}$ & $392.55 \mathrm{~b}$ \\
\hline 50 & $2.89 \mathrm{~b}$ & $105.63 \mathrm{a}$ & $293.06 \mathrm{c}$ \\
\hline 25 & $1.39 \mathrm{c}$ & $107.25 \mathrm{a}$ & $156.70 \mathrm{~d}$ \\
\hline $5 \% \mathrm{LSD}$ & 0.684 & - & 80.33 \\
\hline
\end{tabular}

Notes: Means followed by the same letters at the same treatments and colomn are not significantly different at $5 \%$ LSD 
Table.3: Individual effect of fruit thinning stage at different fruitlet size and percentage of retained fruitlets on a branch on fruit diameter, fruit acid content, ratio fruit sugar:acid content and fruit moisture content

\begin{tabular}{|c|c|c|c|c|}
\hline Treatments & $\begin{array}{c}\text { Fruit diameter } \\
(\mathrm{cm})\end{array}$ & $\begin{array}{c}\text { Fruit acid content } \\
(\mathrm{ppm})\end{array}$ & $\begin{array}{c}\text { Ratio fruit } \\
\text { sugar:acid } \\
\text { content }\end{array}$ & $\begin{array}{c}\text { Fruit moisture } \\
\text { content }(\%)\end{array}$ \\
\hline Stage of thinning at fruitlet size & \multicolumn{5}{|l|}{} \\
\hline $10 \mathrm{~mm}$ & $6,05 \mathrm{c}$ & $1,47 \mathrm{~b}$ & $7,34 \mathrm{a}$ & $88,65 \mathrm{a}$ \\
\hline $30 \mathrm{~mm}$ & $6,66 \mathrm{a}$ & $1,23 \mathrm{~b}$ & $7,39 \mathrm{a}$ & $89,24 \mathrm{a}$ \\
\hline $50 \mathrm{~mm}$ & $6,31 \mathrm{~b}$ & $1,74 \mathrm{a}$ & $5,52 \mathrm{~b}$ & $89,19 \mathrm{a}$ \\
\hline $5 \%$ LSD & 0,166 & 0,246 & 1,285 & - \\
\hline Percentage of retained fruitlets on a branch (\%) & $1,34 \mathrm{a}$ & $7,15 \mathrm{a}$ & $88,91 \mathrm{a}$ \\
\hline 100 & $6,36 \mathrm{a}$ & $1,49 \mathrm{a}$ & $6,54 \mathrm{a}$ & $88,83 \mathrm{a}$ \\
\hline 75 & $6,39 \mathrm{a}$ & $1,60 \mathrm{a}$ & $6,49 \mathrm{a}$ & $89,07 \mathrm{a}$ \\
\hline 50 & $6,24 \mathrm{a}$ & $1,49 \mathrm{a}$ & $6,83 \mathrm{a}$ & $89,32 \mathrm{a}$ \\
\hline 25 & $6,38 \mathrm{a}$ & - & - & - \\
\hline $5 \%$ LSD & - &
\end{tabular}

Notes: Means followed by the same letters at the same treatments and colomn are not significantly different at 5\% LSD 